\title{
Immunohistochemical characterization of the arcuate kisspeptin/ neurokinin B/dynorphin (KNDy) and preoptic kisspeptin neuronal populations in the hypothalamus during the estrous cycle in heifers
}

\author{
Ahmed Saad Ahmed HASSANEEN ${ }^{1{ }^{*}}$, Yousuke NANIWA ${ }^{1)}$, Yuta SUETOMI ${ }^{1)}$, \\ Shuichi MATSUYAMA ${ }^{2)}$, Koji KIMURA ${ }^{3)}$, Nahoko IEDA ${ }^{1)}$, Naoko INOUE ${ }^{1)}$, \\ Yoshihisa UENOYAMA ${ }^{1)}$, Hiroko TSUKAMURA ${ }^{1}$, , Kei-ichiro MAEDA ${ }^{4)}$, \\ Fuko MATSUDA ${ }^{4)}$ and Satoshi OHKURA ${ }^{1)}$ \\ 1) Graduate School of Bioagricultural Sciences, Nagoya University, Nagoya 464-8601, Japan \\ 2) National Agriculture and Food Research Organization (NARO) Institute of Livestock and Grassland Science, \\ Nasushiobara 329-2793, Japan \\ ${ }^{3)}$ Graduate School of Environmental and Life Science, Okayama University, Okayama 700-8530, Japan \\ 4) Graduate School of Agricultural and Life Sciences, The University of Tokyo, Tokyo 113-8657, Japan \\ \#Department of Theriogenology, Obstetrics, and Artificial Insemination, Faculty of Veterinary Medicine, South Valley \\ University, Qena 83523, Egypt
}

\begin{abstract}
Elucidating the physiological mechanisms that control reproduction is an obvious strategy for improving the fertility of cattle and developing new agents to control reproductive functions. The present study aimed to identify kisspeptin neurons in the bovine hypothalamus, clarifying that a central mechanism is also present in the cattle brain, as kisspeptin is known to play an important role in the stimulation of gonadotropin-releasing hormone $(\mathrm{GnRH}) /$ gonadotropin secretion in other mammals. To characterize kisspeptin neurons in the bovine hypothalamus, the co-localizations of kisspeptin and neurokinin B (NKB) or kisspeptin and dynorphin A (Dyn) were examined. Hypothalamic tissue was collected from Japanese Black or Japanese Black $\times$ Holstein crossbred cows during the follicular and luteal phases. Brain sections, including the arcuate nucleus (ARC) and the preoptic area (POA), were dual immunostained with kisspeptin and either NKB or Dyn. In the ARC, both NKB and Dyn were co-localized in kisspeptin neurons during both the follicular and luteal phases, demonstrating the presence of kisspeptin/NKB/Dyn-containing neurons, referred to as KNDy neurons, in cows. In the POA, no co-localization of kisspeptin with either NKB or Dyn was detected. Kisspeptin expression in the follicular phase was higher than that in the luteal phase, suggesting that kisspeptin expression in the POA is positively controlled by estrogen in cows. The kisspeptin neuronal populations in the ARC and POA likely play important roles in regulating the GnRH pulse and surge, respectively, in cows.
\end{abstract} Key words: Estrogen, Estrous cycle, Heifers, Immunohistochemistry, KNDy

(J. Reprod. Dev. 62: 471-477, 2016)

C attle production is an important part of agriculture in Egypt to meet a growing national demand for beef and milk products. In tropical and subtropical areas, crossbreeding of native cows with pure European breeds, such as Holstein Friesian and Brown Swiss, is used in beef and dairy production, because crossbreeds are much more adaptive to such climates than pure breeds [1-3]. However, crossbred cows still exhibit relatively poor rates of fertility and low productivity in tropical and subtropical climates. To overcome such problems, it is critical to identify the mechanisms controlling reproductive function in cattle, such as steroidogenesis, follicular development, or ovulation. Better understanding of the mechanisms

Received: May 13, 2016

Accepted: May 25, 2016

Published online in J-STAGE: June 27, 2016

(C)2016 by the Society for Reproduction and Development

Correspondence: S Ohkura (e-mail: saohkura@agr.nagoya-u.ac.jp)

This is an open-access article distributed under the terms of the Creative Commons Attribution Non-Commercial No Derivatives (by-nc-nd) License $<$ http://creativecommons.org/licenses/by-nc-nd/4.0/>. regulating reproduction would contribute to the genetic improvement of fertility or to the development of novel agents that would stimulate the reproductive axis.

Gonadotropin-releasing hormone $(\mathrm{GnRH})$ plays a pivotal role in controlling reproductive functions via two modes of secretion in females. One is pulsatile secretion, which induces gonadotropin pulses, which in turn stimulates follicular development and steroidogenesis. The other is surge secretion, which induces luteinizing hormone (LH) surge followed by ovulation. Accumulating evidence suggests that kisspeptin neurons are closely associated with both types of $\mathrm{GnRH}$ release, and therefore, these neurons are considered to be a master regulator of reproduction in many mammalian species [4-10]. Indeed, administration of kisspeptin, or its analogs, stimulates gonadotropin secretion in cattle [11-13], suggesting that kisspeptin neurons are involved in regulating GnRH and subsequent gonadotropin release in cattle.

Kisspeptin neuronal cell bodies are located in two major hypothalamic areas in mammalian species examined to date $[4,14]$, with one population in the hypothalamic arcuate nucleus (ARC). Because 
the ARC kisspeptin neurons co-express two other neuropeptides, neurokinin $\mathrm{B}(\mathrm{NKB})$ and dynorphin A (Dyn), these neurons are collectively referred to as KNDy neurons [15-20]. The KNDy neurons are implied to be responsible for the control of pulsatile GnRH release. In goats, for instance, periodic increases in multiple unit activity (MUA) volleys recorded in close proximity to the ARC KNDy neurons are closely associated with LH pulses in goats $[18,21]$. Central administration of NKB agonist or Dyn antagonist increases the frequency of MUA volleys and LH pulses, whereas Dyn decreases them in goats $[18,22]$. Similarly, LH pulses are positively or negatively regulated by NKB or Dyn, respectively, in rodents [23-25]. Recently, kisspeptin immunoreactivity was found in the ARC in cows [26-28], with one study reporting that Dyn immunoreactivity is localized in bovine ARC [26]. These studies imply that the presence of KNDy neurons in the bovine ARC to control pulsatile GnRH/gonadotropin release. However, to our knowledge, no direct evidence has definitively determined the presence of KNDy neurons in cows. The presence of KNDy neurons in cows would be of great importance, because it would improve our understanding of the mechanisms by which these neuropeptides control GnRH/ gonadotropin pulses, and consequent follicular development and steroidogenesis in cows.

The other kisspeptin neuronal population is located more rostrally, in the preoptic area (POA) of sheep [29, 30], goats [31], and primates $[32,33]$; in the anteroventral periventricular nucleus (AVPV) of rodents [34, 35]; or in the periventricular nucleus of pigs [36]. The anterior hypothalamic population of kisspeptin neurons in the POA/ AVPV is thought to be involved in the control of the surge mode of GnRH release and then ovulation. A preovulatory level of estrogen induces an LH surge and increases AVPV Kiss 1 mRNA expression in rodents $[35,37]$. KISS1 mRNA expression in the POA is higher in the late follicular phase than in the luteal phase in sheep [38]. In addition, c-Fos expression in the kisspeptin neurons of the POA is induced by preovulatory levels of estrogen in goats and monkeys $[31,33]$. These findings suggest that kisspeptin neurons in the POA play an essential role in generating GnRH/LH surges. Previous studies have demonstrated that little kisspeptin immunoreactivity was found in the anterior hypothalamus, including the POA, in cows [26-28]. Thus, it is unknown whether anterior hypothalamic kisspeptin neurons are involved in the mechanisms regulating $\mathrm{GnRH}$ surge and consequent ovulation in cows.

The present study aimed to determine the presence of the ARC KNDy and POA kisspeptin neurons in the cow brain in order to gain a better understanding of the mechanisms controlling ovarian functions. To address these issues, we examined the co-localization of kisspeptin and NKB/Dyn immunoreactivity in the bovine hypothalamus. Because kisspeptin expression is regulated by ovarian steroids, kisspeptin, $\mathrm{NKB}$, and Dyn expressions during the follicular and luteal phases in cows were examined.

\section{Materials and Methods}

\section{Animals}

Fifteen- to 23-month-old Japanese Black (follicular phase, $\mathrm{n}=2$; luteal phase, $n=2$ ) or crossbred Japanese Black $\times$ Holstein (follicular phase, $\mathrm{n}=2$; luteal phase, $\mathrm{n}=2$ ) heifers weighing between $291 \mathrm{~kg}$ and $463 \mathrm{~kg}$ were used. All animals were maintained under natural conditions at the National Agriculture and Food Research Organization (NARO) Institute of Livestock and Grassland Science. All procedures involving animals were approved by the Committees of the Care and Use of Experimental Animals at the NARO Institute of Livestock and Grassland Science and the Graduate School of Bioagricultural Sciences, Nagoya University.

\section{Control of estrous cycle}

Animals were treated with a progesterone-releasing intravaginal device (PRID; ASKA Pharmaceutical, Tokyo, Japan) for 6 days, and then intramuscularly injected with a prostaglandin $\mathrm{F}_{2 \alpha}\left(\mathrm{PGF}_{2 \alpha}\right)$ analog $(0.75 \mathrm{mg}$, cloprostenol sodium; Nippon Zenyaku Kogyo, Koriyama, Japan) to synchronize the estrous cycle. Brain samples were collected 2 days and 7 days after the $\mathrm{PGF}_{2 \alpha}$ injection for the follicular and luteal phases, respectively. Visual inspection of ovaries at the time of slaughter was performed: antral follicles but no corpus luteum were found in the ovaries collected 2 days after the $\mathrm{PGF}_{2 \alpha}$ injection, whereas corpora lutea and some follicles were found in the ovaries collected 7 days after the injection. Two out of the 4 heifers slaughtered 2 days after the $\mathrm{PGF}_{2 \alpha}$ injection showed clear estrous behavior, whereas no obvious estrous behavior was observed for the other 2 heifers. Four heifers slaughtered 7 days after the $\mathrm{PGF}_{2 \alpha}$ injection displayed clear estrous behavior 2 days after the $\mathrm{PGF}_{2 \alpha}$ injection.

\section{Brain and blood sampling}

Blood samples $(10 \mathrm{ml})$ were collected via the jugular vein immediately prior to brain sampling. Plasma samples separated by centrifugation were stored at $-30^{\circ} \mathrm{C}$ until estradiol and progesterone assays were performed. Heifers were then intravenously injected with 60-260 mg of xylazine (Bayer Yakuhin, Osaka, Japan), 500,000 U of heparin, and an overdose $(6,480 \mathrm{mg} /$ heifer $)$ of sodium pentobarbital (Kyoritsu Seiyaku, Tokyo, Japan). All heifers were bilaterally perfused through the carotid arteries with 101 of $10 \mathrm{mM}$ phosphate buffered saline (PBS) containing 13,000 U heparin/liter and $0.7 \%$ sodium nitrite, followed by $10-151$ of $4 \%$ paraformaldehyde in a $100 \mathrm{mM}$ phosphate buffer (PB; pH 7.4) as a fixative. Brain blocks containing the hypothalamus were collected, with each brain block subsequently divided into two parts: an anterior part containing the POA and a posterior part containing the ARC. Brain blocks were immersed in the same fixative overnight at $4^{\circ} \mathrm{C}$ and then placed in a solution of $30 \%$ sucrose in $100 \mathrm{mM} \mathrm{PB}, \mathrm{pH} 7.4$, at $4^{\circ} \mathrm{C}$, until the block sank. Serial brain sections were cut at $50-\mu \mathrm{m}$ thickness on a cryostat with reference to a brain atlas of cattle [39]. All sections were stored in a cryoprotectant consisting of $25 \mathrm{mM}$ PBS containing $50 \%$ glycerol, $250 \mathrm{mM}$ sucrose, and $3.2 \mathrm{mM}$ magnesium chloride at $-20^{\circ} \mathrm{C}$ until used for immunohistochemistry.

\section{Dual immunohistochemistry of kisspeptin and NKB/Dyn}

Every twelfth section of the hypothalamus was subjected to dual immunostaining of kisspeptin and NKB. Three sections containing either the ARC or POA were selected according to a bovine brain atlas [39]. Sections from the rostral edge of the dorsomedial hypothalamic nucleus (DMH) to the rostral edge of the mammillary bodies were used for the $\mathrm{ARC}$, and those from the rostral end of the organum 
vasculosum of the lamina terminalis (OVLT) to the rostral edge of the hypothalamic paraventricular nucleus (PVN) were used for the POA. After rinsing with $0.1 \mathrm{M}$ PB three times for 5 min each time, free-floating sections were subjected to antigen retrieval in $10 \mathrm{mM}$ sodium citrate solution ( $\mathrm{pH} \mathrm{9.0)} \mathrm{for} 30 \mathrm{~min}$ at $80^{\circ} \mathrm{C}$ [40], then allowed to cool to room temperature and rinsed three times with $0.05 \mathrm{M}$ PBS. The sections were then rinsed three more times (15 min each time) with 0.05 M PBS containing $0.3 \%$ Triton X-100 (PBST) and incubated with PBST containing $1.5 \%$ blocking reagent (Roche Diagnostics, Mannheim, Germany) for $1.5 \mathrm{~h}$. The sections were incubated with the same buffer containing a mouse monoclonal kisspeptin antibody $(1: 4,000$; Takeda No. 254) and a rabbit polyclonal antibody to NKB (1:4,000; Peninsula Laboratories, San Carlos, CA, USA) for $72 \mathrm{~h}$ at $4^{\circ} \mathrm{C}$. The sections were then washed four times ( $15 \mathrm{~min}$ each time) with PBST and incubated with Alexa 555-conjugated goat anti-mouse IgG (1:200; Life Technologies, Carlsbad, CA, USA) and Alexa 488-conjugated goat anti-rabbit IgG (1:200; Life Technologies) for $2 \mathrm{~h}$ under light shielding at room temperature. After washing, the sections were mounted on silane-coated slides and cover-slipped with a water-soluble anti-fade mounting reagent (Prolong Gold; Invitrogen, Carlsbad, CA, USA). Immunofluorescence was observed under a microscope (BX53; Olympus, Tokyo, Japan) equipped with a CCD camera (DP73; Olympus) and the merged images were obtained with the aid of computer software (Photoshop; Adobe Systems, San Jose, CA, USA). To confirm the specificity of the antibodies, brain sections were incubated with kisspeptin or NKB antibodies, which were preabsorbed overnight with $0.1 \mathrm{nmol} / \mu \mathrm{l}$ of bovine kisspeptin-53 (donated by Dr. S. Oishi, Kyoto University) or $0.1 \mathrm{nmol} / \mu 1$ of NKB (Sigma-Aldrich, St. Louis, MO, USA), respectively. Preincubation of the antibodies with corresponding peptides completely eliminated positive signals (data not shown).

Every twelfth section of the hypothalamus containing the ARC or POA was subjected to dual immunostaining of kisspeptin and Dyn. Immunohistochemical analysis was performed with the same method described above, using rabbit polyclonal antibody to Dyn as the first antibody (1:4,000; Phoenix Pharmaceuticals, Burlingame, CA, USA). To confirm specificity of antibodies, brain sections were incubated with the kisspeptin or Dyn antibodies, which were preabsorbed with $0.1 \mathrm{nmol} / \mu \mathrm{l}$ of bovine kisspeptin-53 or $1 \mathrm{nmol} /$ $\mu 1$ of Dyn (Phoenix Pharmaceuticals), respectively. Preincubation of the antibodies with corresponding peptides eliminated positive signals (data not shown).

\section{Radioimmunoassay}

Plasma estradiol and progesterone concentrations were determined using radioimmunoassay. To determine plasma estradiol concentrations, 2-ml plasma samples were extracted with diethyl ether (Dojindo Laboratories, Kamimashiki, Japan), defatted with n-hexane 5000 (Wako Pure Chemical Industries, Osaka, Japan), and then reconstituted in $0.05 \mathrm{M}$ PBS ( $\mathrm{pH} 7.5$ ) containing $0.1 \%$ sodium azide and $0.1 \%$ gelatin. Synthetic estradiol (Sigma-Aldrich) as standard, a rabbit antiserum against estradiol (1:100,000; GDN244), and tritiated estradiol (PerkinElmer, Waltham, MA, USA) were used. The lowest detectable concentration of estradiol was $0.39 \mathrm{pg} / \mathrm{ml}$ and intra-assay coefficients of variation were $9.5 \%$ at $1.6 \mathrm{pg} / \mathrm{ml}$ and $14.2 \%$ at $6.7 \mathrm{pg} /$ $\mathrm{ml}$. To determine plasma progesterone concentrations, unextracted plasma samples $(20 \mu \mathrm{l})$ were used, along with synthetic progesterone (Sigma-Aldrich) as a standard, a rabbit antiserum for progesterone (1:30,000; OK-1), and tritiated progesterone (PerkinElmer). The lowest detectable concentration of progesterone was $0.625 \mathrm{ng} / \mathrm{ml}$ and intra-assay coefficients of variation were $3.9 \%$ at $3.0 \mathrm{ng} / \mathrm{ml}$ and $5.6 \%$ at $13 \mathrm{ng} / \mathrm{ml}$. The radioimmunoassay was performed at the Radioisotope Research Center, Nagoya University.

\section{Statistical analysis}

Statistical differences $(\mathrm{P}<0.05)$ in plasma estradiol and progesterone concentrations between the follicular and luteal phases were determined using Student's $t$-test.

\section{Results}

\section{Plasma estradiol and progesterone concentrations}

Plasma estradiol concentrations in the follicular phase were significantly $(\mathrm{P}<0.05)$ higher than those in the luteal phase (Fig. 1A). On the other hand, plasma progesterone concentrations in the follicular phase were significantly $(\mathrm{P}<0.05)$ lower than in the luteal phase (Fig. 1B).

\section{Dual immunohistochemistry of kisspeptin and NKB/Dyn in} the bovine ARC during the follicular and luteal phases

Figure 2 shows the co-localization of kisspeptin and NKB immunoreactivity (Fig. 2A) and kisspeptin and Dyn immunoreactivity (Fig. 2B) in the ARC of representative cows during the follicular or luteal phase. The kisspeptin-immunoreactive cell bodies and fibers were detected throughout the ARC in both the follicular and luteal phases (Fig. 2), and kisspeptin-immunoreactive fibers extended to the median eminence (Supplementary Fig. 1: online only). NKBimmunoreactive cell bodies and fibers were also detected throughout the ARC (Fig. 2A), and immunoreactivity was widely distributed in the ARC beyond the kisspeptin immunoreactivity. It should be noted that almost all kisspeptin-immunoreactive cell bodies co-expressed
A

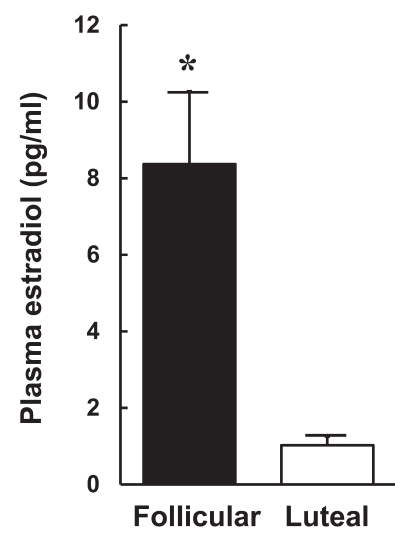

B

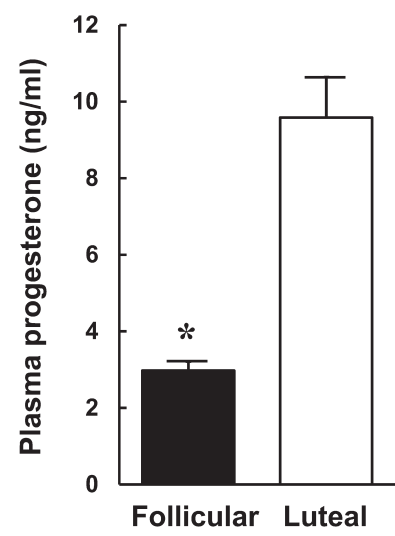

Fig. 1. Plasma estradiol (A) and progesterone (B) concentrations during the follicular $(n=4)$ and luteal $(n=4)$ phases in cows. Values are shown as mean \pm SEM. * $\mathrm{P}<0.05$ between the follicular and luteal phases. 

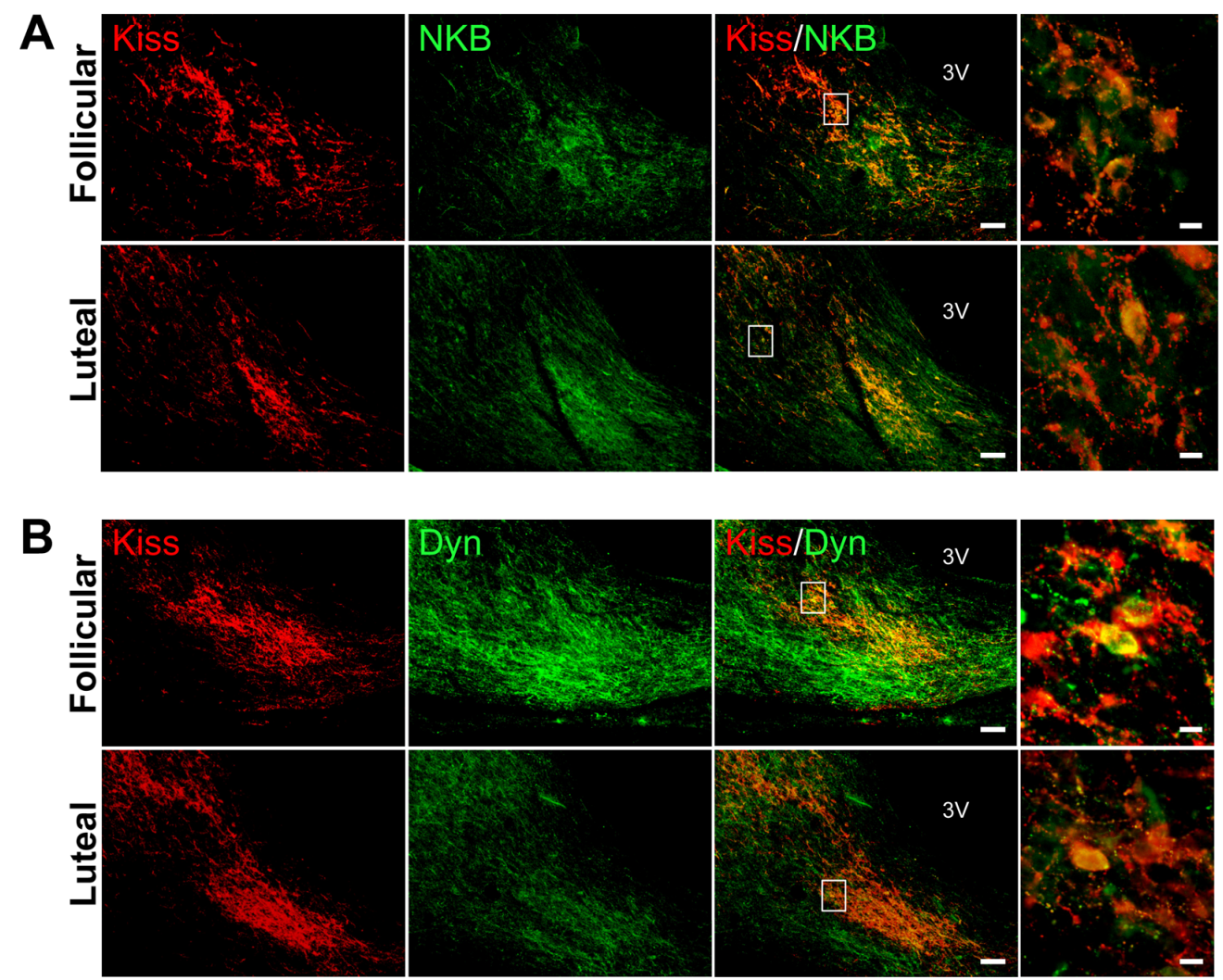

Fig. 2.

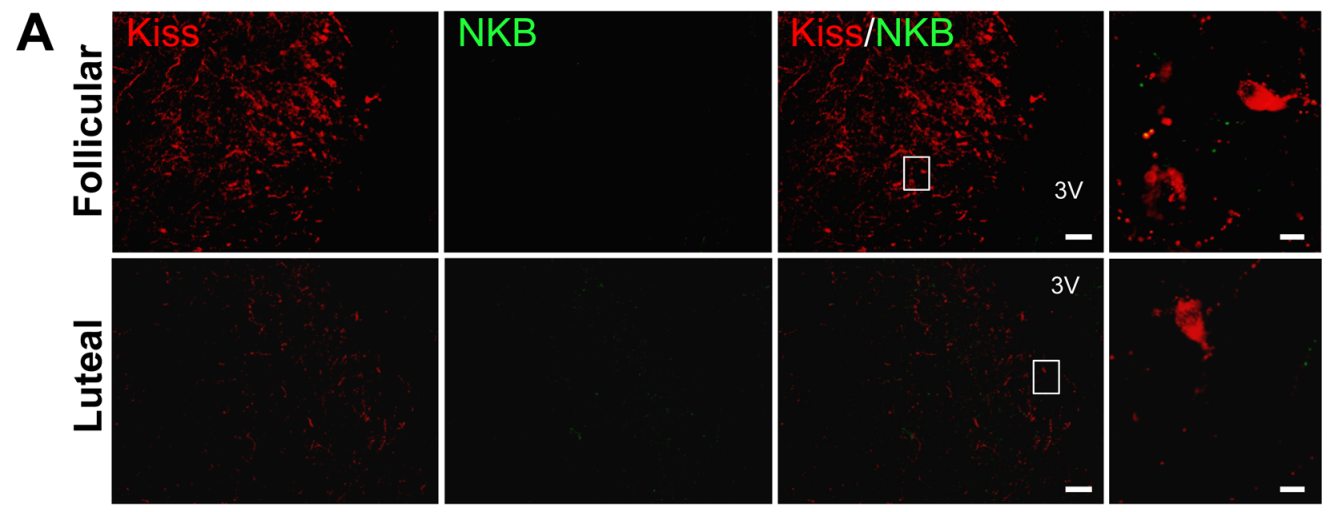

B

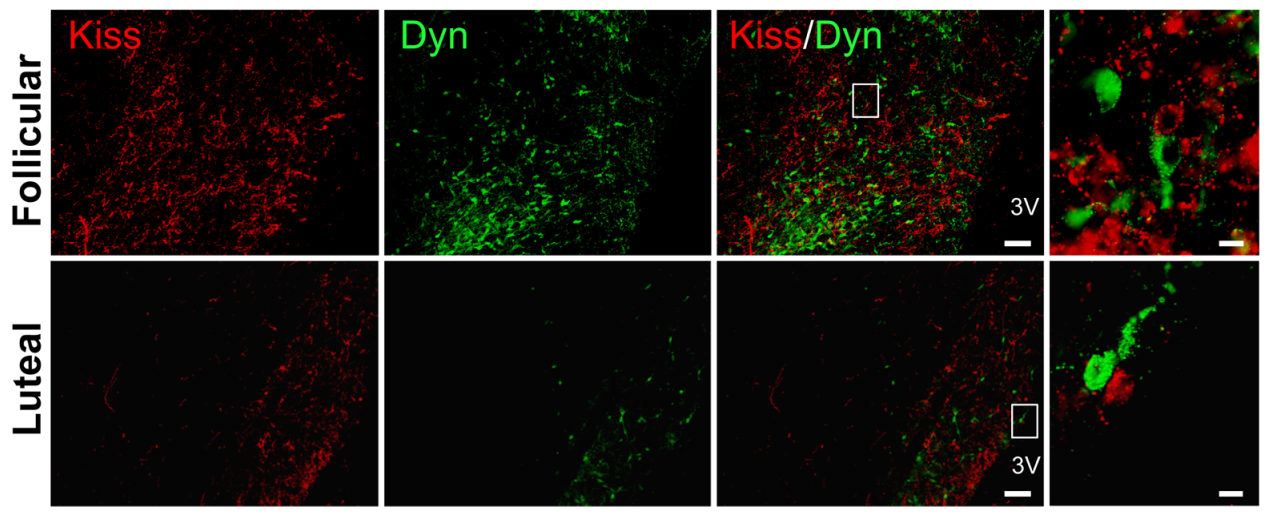

Fig. 3. 
NKB immunoreactivity (Fig. 2A, right panel), with similar results observed in all of the cows ( $\mathrm{n}=4$ in each group) we examined.

Dynorphin A-immunoreactive cell bodies and fibers were distributed throughout the ARC in both the follicular and luteal phases (Fig. 2B). In the bovine ARC, more than half of the kisspeptin-immunoreactive cell bodies also exhibited Dyn immunoreactivity (Fig. 2B, right panel). The Dyn-immunoreactive fibers extended ventrolaterally in the ARC in both the follicular and luteal phases when compared with kisspeptin-immunoreactive fibers. Dyn immunoreactivity was detected in a wider area in the bovine ARC in the follicular phase than in the luteal phase (Fig. 2B).

\section{Dual immunohistochemistry of kisspeptin and NKB/Dyn in the bovine POA during the follicular and luteal phases}

Figure 3 shows the localization of kisspeptin and NKB immunoreactivity (Fig. 3A), and kisspeptin and Dyn immunoreactivity (Fig. 3B), in the POA of representative cows during the follicular or luteal phases. Numerous kisspeptin-immunoreactive cell bodies were detected in the POA in the follicular phase, whereas only a few were found in the luteal phase (Figs. 3A and 3B). Unlike in the ARC, few NKB-immunoreactive cell bodies and fibers were found in the bovine POA in either the follicular or luteal phase (Fig. 3A). Kisspeptin-immunoreactive fibers were distributed throughout the POA (Figs. 3A and 3B), whereas Dyn-immunoreactive fibers were mainly detected in the medial part of the POA (Fig. 3B). There were more Dyn-immunoreactive cell bodies and fibers in the follicular phase than in the luteal phase (Fig. 3B), and Dyn-immunoreactive cell bodies were in close apposition to kisspeptin neurons (Fig. 3B, right panel). No NKB- or Dyn-immunoreactivity was found in the POA kisspeptin-positive cells. Similar results were observed in all of the cows ( $n=4$ in each group) we examined.

\section{Distribution of kisspeptin immunoreactivity in other hypothalamic areas}

Kisspeptin immunoreactivity was found in other hypothalamic nuclei, including the OVLT, PVN, DMH, ventromedial hypothalamic nucleus (VMH), and lateral hypothalamus $(\mathrm{LaH})$ (Supplementary Fig. 1). Some kisspeptin-immunoreactive cell bodies and fibers were found in the OVLT, whereas only immunoreactive fibers were detected in the PVN, DMH, VMH, and $\mathrm{LaH}$.

\section{Discussion}

The present study provides direct evidence of the presence of ARC KNDy neurons as well as POA kisspeptin neurons in the bovine brain. The distribution of kisspeptin neurons was consistent with that observed in other mammalian species [18, 29-31, 34-36]. As the two kisspeptin neuronal populations are known to regulate GnRH release [18, 22, 31, 33, 37, 41], these neurons are also likely to be involved in the regulation of $\mathrm{GnRH} /$ gonadotropin release in cows. More specifically, we found a population of kisspeptin neurons co-localized with NKB or Dyn in the ARC, suggesting that the bovine KNDy neurons may have a role in GnRH pulse generation, as has been suggested in goats [18]. A second population of kisspeptin neurons found in abundance in the POA during the follicular phase may be involved in the GnRH/LH surge, as has been suggested in both sheep [29, 30] and goats [31]. Therefore, ARC KNDy and POA kisspeptin neuronal populations might be possible therapeutic targets for improving fertility in cattle raised in tropical and subtropical areas.

The presence of KNDy neurons in the ARC of cows was demonstrated by the co-localization of NKB or Dyn in the ARC kisspeptin neurons. KNDy neurons have been suggested to be the neuronal population that is essential for pulsatile $\mathrm{GnRH}$ release in goats and sheep $[18,21,42]$. The dense distribution of KNDy neurons from the middle to the caudal parts of the bovine ARC is consistent with previous findings in sheep [17] and goats [18], suggesting that the ARC KNDy neurons also form a dense network in cows, most likely to facilitate the synchronization of their activity. The dense network is a reminder of electrophysiological results in goats, in which MUA volleys in the ARC reflect the GnRH pulse generator activity [18]. The presence of kisspeptin-immunoreactive fibers in the median eminence further suggests that kisspeptin is released in the median eminence by the KNDy neurons to control GnRH release at GnRH nerve terminals [26]. Previous histological studies have shown that the nerve terminals of kisspeptin neurons make direct contact with GnRH nerve terminals at the median eminence in both goats [43] and rats [44]. The current results show that kisspeptin expression is evident in both the follicular and luteal phases, as previously reported in sheep and goats $[38,45]$. This suggests that KNDy neurons are functional throughout the estrous cycle and regulate follicular development and corpus luteum function via the pulsatile release of $\mathrm{GnRH} /$ gonadotropins in cows. In addition, the ARC Dyn immunoreactivities were more widely distributed in the follicular phase than in the luteal phase in cows. In mice, estrogen has been reported to suppress Dyn gene expression in the ARC [46]: it is possible then that Dyn peptides accumulate in the ARC neurons because of the suppression of peptide release. Further studies are required to examine the relationship between the Dyn peptide and gene expression in the ARC of cows.

It is likely that kisspeptin expression in the POA is positively

Fig. 2. Expression of kisspeptin, neurokinin B (NKB), and dynorphin A (Dyn) in the hypothalamic arcuate nucleus (ARC) in cows. (A) Representative photomicrographs showing dual immunohistochemistry for kisspeptin (red) and NKB (green) during the follicular and luteal phases. The merged images show the co-localization of kisspeptin and NKB in the ARC. (B) Representative photomicrographs showing dual immunohistochemistry for kisspeptin (red) and Dyn (green) during the follicular and luteal phases. The merged images show the co-localization of kisspeptin and Dyn in the ARC. The white boxes in the merged images show the areas of the magnified images. Scale bars are $100 \mu \mathrm{m}$ and $10 \mu \mathrm{m}$ in the merged and magnified images, respectively. $3 \mathrm{~V}$, third ventricle.

Fig. 3. Expression of kisspeptin, neurokinin B (NKB), and dynorphin A (Dyn) in the preoptic area (POA) in cows. (A) Representative photomicrographs showing dual immunohistochemistry for kisspeptin (red) and NKB (green) during the follicular and luteal phases. The merged images show the absence of co-localization of kisspeptin and NKB in the POA. (B) Representative photomicrographs showing dual immunohistochemistry for kisspeptin (red) and Dyn (green) during the follicular and luteal phases. The merged images show the absence of co-localization of kisspeptin and Dyn in the POA. The white boxes in the merged images show the areas of the magnified images. Scale bars are $100 \mu \mathrm{m}$ and $10 \mu \mathrm{m}$ in the merged and magnified images, respectively. $3 \mathrm{~V}$, third ventricle. 
controlled by ovarian estrogen in cows. This is supported by the results of the present study, in which the density of POA kisspeptin immunoreactivity was found to be higher in the follicular phase than in the luteal phase. These results are consistent with previous studies demonstrating that estrogen positively regulates $K I S S 1 /$ kisspeptin expression in the POA/AVPV of goats, rodents, and monkeys [31, 33, 37]. A high level of circulating estrogen is capable of inducing LH surges in cows [47], probably through estrogen receptor $\alpha$ in bovine kisspeptin neurons in the POA, as has been demonstrated in mice $[35,48]$. The POA kisspeptin neuronal population, therefore, would likely be involved in the $\mathrm{GnRH} / \mathrm{LH}$ surge generation induced by high circulating estrogen in cows, as has been shown in other species [ 31 , $33,37,38]$. The positive effect of estrogen on kisspeptin expression is supported by previous studies showing few kisspeptin-immunoreactive cell bodies in the bovine POA of juvenile prepubertal heifers [27, 28], in which the circulating level of estrogen remains suppressed. Lower expression of POA kisspeptin during the luteal phase is unlikely to be due to the high progesterone level in this phase compared with that in the follicular phase, because progesterone treatment alone failed to affect KISS1 expression in the POA in ewes [29]. The notion is supported by a recent study in cows showing that plasma progesterone levels are not associated with POA kisspeptin immunoreactivity [26]. In the present study, kisspeptin immunoreactivity was in close apposition to Dyn immunoreactivity in the POA during the follicular phase in cows, and exhibited no co-localization with either NKB or Dyn immunoreactivity, which is in keeping with the results of a previous study of sheep [17]. The current result that Dyn expression is higher in the follicular phase than in the luteal phase suggests that Dyn is involved in the regulation of the GnRH surge. A kappa opioid receptor, a receptor for Dyn, agonist has been reported to control the activity of kisspeptin neurons in the rostral periventricular preoptic area (equivalent to the POA kisspeptin neuronal population in cows) in high estrogen-treated ovariectomized mice [49]. Further studies are required in order to clarify the role of POA Dyn neurons in controlling kisspeptin/GnRH neuronal activities in cows.

Kisspeptin-immunoreactive cell bodies and fibers found in the OVLT suggest that kisspeptin acts on the OVLT to regulate GnRH release, as a dense distribution of $\mathrm{GnRH}$ neuronal cell bodies and fibers are found in the OVLT of cows [26]. Kisspeptin-immunoreactive fibers were found in other hypothalamic areas, including the PVN, DMH, $\mathrm{VMH}$, and $\mathrm{LaH}$, in which few GnRH-immunoreactive cell bodies are found in cows [26], similar to the kisspeptin-immunoreactive fibers found in the OVLT, PVN, DMH, and VMH of rats [50]. The role of kisspeptin located in these areas, however, remains unknown and should be clarified by further studies.

In conclusion, the present study demonstrated that there are two major populations of kisspeptin neurons in the cow hypothalamus, as has been reported in other mammalian species. This finding suggests that the ARC KNDy neurons and POA kisspeptin neurons are involved in $\mathrm{GnRH}$ release in cows. These results can be used as the basis for future therapeutic trials solving the common infertility problems of cows experienced in tropical and subtropical areas.

\section{Acknowledgments}

The authors would like to thank Dr H Matsui, Takeda Pharma- ceutical Co., Ltd., for providing anti-rat kisspeptin monoclonal antibody (Takeda No. 254); Dr S Oishi, Kyoto University, for providing bovine kisspeptin-53; Dr GD Niswender, Colorado State University, for providing anti-estradiol antiserum (GDN244); and Dr K Okuda, Obihiro University of Agriculture and Veterinary Medicine, for providing anti-progesterone antiserum (OK-1). We are also grateful to Mr M Kato, Mr T Sasaki, Mr K Okuda, Mr D Ito, Ms R Ozaki, Ms K Yamasaki, Mr F Yoshimura, and Mr Y Kono for technical assistance, and to Vet El-Sayed S Ibrahim, Hiroshima University, for his valuable comments regarding immunocytochemistry. The radioimmunoassay was performed at the Radioisotope Research Center, Nagoya University. The present study was supported in part by the Research Program on Innovative Technologies for Animal Breeding, Reproduction and Vaccine Development (REP2005 to SO) from the Ministry of Agriculture, Forestry and Fisheries of Japan, and the JSPS KAKENHI Grant Numbers 24380154 and $15 \mathrm{~K} 14842$ to SO, 26252046 to HT, and $15 \mathrm{H} 05782$ to KM. ASAH was financially supported by a full PhDexternal mission scholarship granted by South Valley University and the Ministry of Higher Education and Research, Egypt. The authors declare that they have no conflicts of interest.

\section{References}

1. Boonkum W, Misztal I, Duangjinda M, Pattarajinda V, Tumwasorn S, Buaban S. Short communication: genetic effects of heat stress on days open for Thai Holstein crossbreds. J Dairy Sci 2011; 94: 1592-1596. [Medline] [CrossRef]

2. Mellado M, Coronel F, Estrada A, Ríos FG. Lactation performance of holstein and holstein x gyr cattle under intensive condition in a subtropical environment. Trop Subtropical Agroecosystems 2011; 14: 927-931.

3. Boonkum W, Misztal I, Duangjinda M, Pattarajinda V, Tumwasorn S, Sanpote J. Genetic effects of heat stress on milk yield of Thai Holstein crossbreds. J Dairy Sci 2011; 94: 487-492. [Medline] [CrossRef]

4. Oakley AE, Clifton DK, Steiner RA. Kisspeptin signaling in the brain. Endocr Rev 2009; 30: 713-743. [Medline] [CrossRef]

5. Okamura H, Yamamura T, Wakabayashi Y. Kisspeptin as a master player in the central control of reproduction in mammals: an overview of kisspeptin research in domestic animals. Anim Sci J 2013; 84: 369-381. [Medline] [CrossRef]

6. Messager S, Chatzidaki EE, Ma D, Hendrick AG, Zahn D, Dixon J, Thresher RR, Malinge I, Lomet D, Carlton MB, Colledge WH, Caraty A, Aparicio SA. Kisspeptin directly stimulates gonadotropin-releasing hormone release via $\mathrm{G}$ protein-coupled receptor 54. Proc Natl Acad Sci USA 2005; 102: 1761-1766. [Medline] [CrossRef]

7. Smith JT. The role of kisspeptin and gonadotropin inhibitory hormone in the seasonal regulation of reproduction in sheep. Domest Anim Endocrinol 2012; 43: 75-84. [Medline] [CrossRef]

8. Goodman RL, Maltby MJ, Millar RP, Hileman SM, Nestor CC, Whited B, Tseng AS, Coolen LM, Lehman MN. Evidence that dopamine acts via kisspeptin to hold GnRH pulse frequency in check in anestrous ewes. Endocrinology 2012; 153: 5918-5927. [Medline] [CrossRef]

9. Hashizume T, Saito H, Sawada T, Yaegashi T, Ezzat AA, Sawai K, Yamashita T. Characteristics of stimulation of gonadotropin secretion by kisspeptin-10 in female goats. Anim Reprod Sci 2010; 118: 37-41. [Medline] [CrossRef]

10. Tanaka T, Ohkura S, Wakabayashi Y, Okamura H. Effect of peripherally administered kisspeptin-10 on GnRH neurosecretion into the hypophyseal portal circulation in ovariectomized goat does. Small Rumin Res 2012; 105: 273-276. [CrossRef]

11. Kadokawa H, Matsui M, Hayashi K, Matsunaga N, Kawashima C, Shimizu T, Kida K, Miyamoto A. Peripheral administration of kisspeptin-10 increases plasma concentrations of GH as well as LH in prepubertal Holstein heifers. J Endocrinol 2008; 196: 331-334. [Medline] [CrossRef]

12. Naniwa Y, Nakatsukasa K, Setsuda S, Oishi S, Fujii N, Matsuda F, Uenoyama Y, Tsukamura H, Maeda K, Ohkura S. Effects of full-length kisspeptin administration on follicular development in Japanese Black beef cows. J Reprod Dev 2013; 59: 588-594. [Medline] [CrossRef]

13. Ezzat Ahmed A, Saito H, Sawada T, Yaegashi T, Yamashita T, Hirata T, Sawai K, Hashizume T. Characteristics of the stimulatory effect of kisspeptin-10 on the secretion 
of luteinizing hormone, follicle-stimulating hormone and growth hormone in prepubertal male and female cattle. J Reprod Dev 2009; 55: 650-654. [Medline] [CrossRef]

14. Skrapits K, Borsay BA, Herczeg L, Ciofi P, Liposits Z, Hrabovszky E. Neuropeptide co-expression in hypothalamic kisspeptin neurons of laboratory animals and the human. Front Neurosci 2015; 9: 29. [Medline] [CrossRef]

15. Navarro VM, Gottsch ML, Chavkin C, Okamura H, Clifton DK, Steiner RA. Regulation of gonadotropin-releasing hormone secretion by kisspeptin/dynorphin/neurokinin B neurons in the arcuate nucleus of the mouse. $J$ Neurosci 2009; 29: 11859-11866. [Medline] [CrossRef]

16. Navarro VM, Castellano JM, McConkey SM, Pineda R, Ruiz-Pino F, Pinilla L, Clifton DK, Tena-Sempere M, Steiner RA. Interactions between kisspeptin and neurokinin $\mathrm{B}$ in the control of GnRH secretion in the female rat. Am J Physiol Endocrinol Metab 2011; 300: E202-E210. [Medline] [CrossRef]

17. Goodman RL, Lehman MN, Smith JT, Coolen LM, de Oliveira CV, Jafarzadehshirazi MR, Pereira A, Iqbal J, Caraty A, Ciofi P, Clarke IJ. Kisspeptin neurons in the arcuate nucleus of the ewe express both dynorphin A and neurokinin B. Endocrinology 2007; 148: 5752-5760. [Medline] [CrossRef]

18. Wakabayashi Y, Nakada T, Murata K, Ohkura S, Mogi K, Navarro VM, Clifton DK, Mori Y, Tsukamura H, Maeda K, Steiner RA, Okamura H. Neurokinin B and dynorphin $\mathrm{A}$ in kisspeptin neurons of the arcuate nucleus participate in generation of periodic oscillation of neural activity driving pulsatile gonadotropin-releasing hormone secretion in the goat. $J$ Neurosci 2010; 30: 3124-3132. [Medline] [CrossRef]

19. Ramaswamy S, Seminara SB, Ali B, Ciofi P, Amin NA, Plant TM. Neurokinin B stimulates GnRH release in the male monkey (Macaca mulatta) and is colocalized with kisspeptin in the arcuate nucleus. Endocrinology 2010; 151: 4494-4503. [Medline] [CrossRef]

20. Lehman MN, Coolen LM, Goodman RL. Minireview: kisspeptin/neurokinin B/dynorphin (KNDy) cells of the arcuate nucleus: a central node in the control of gonadotropin-releasing hormone secretion. Endocrinology 2010; 151: 3479-3489. [Medline] [CrossRef]

21. Ohkura S, Takase K, Matsuyama S, Mogi K, Ichimaru T, Wakabayashi Y, Uenoyama Y, Mori Y, Steiner RA, Tsukamura H, Maeda KI, Okamura H. Gonadotrophin-releasing hormone pulse generator activity in the hypothalamus of the goat. $J$ Neuroendocrinol 2009; 21: 813-821. [Medline] [CrossRef]

22. Yamamura T, Wakabayashi Y, Ohkura S, Navarro VM, Okamura H. Effects of intravenous administration of neurokinin receptor subtype-selective agonists on gonadotropinreleasing hormone pulse generator activity and luteinizing hormone secretion in goats. $J$ Reprod Dev 2015; 61: 20-29. [Medline] [CrossRef]

23. Mostari P, Ieda N, Deura C, Minabe S, Yamada S, Uenoyama Y, Maeda K, Tsukamura H. Dynorphin-kappa opioid receptor signaling partly mediates estrogen negative feedback effect on LH pulses in female rats. J Reprod Dev 2013; 59: 266-272. [Medline] [CrossRef]

24. Ruiz-Pino F, Garcia-Galiano D, Manfredi-Lozano M, Leon S, Sánchez-Garrido MA, Roa J, Pinilla L, Navarro VM, Tena-Sempere M. Effects and interactions of tachykinins and dynorphin on FSH and LH secretion in developing and adult rats. Endocrinology 2015; 156: 576-588. [Medline] [CrossRef]

25. Nakahara T, Uenoyama $\mathbf{Y}$, Iwase A, Oishi S, Nakamura S, Minabe S, Watanabe $\mathbf{Y}$, Deura C, Noguchi T, Fujii N, Kikkawa F, Maeda K, Tsukamura H. Chronic peripheral administration of kappa-opioid receptor antagonist advances puberty onset associated with acceleration of pulsatile luteinizing hormone secretion in female rats. J Reprod Dev 2013; 59: 479-484. [Medline] [CrossRef]

26. Tanco VM, Whitlock BK, Jones MA, Wilborn RR, Brandebourg TD, Foradori CD. Distribution and regulation of gonadotropin-releasing hormone, kisspeptin, RF-amide related peptide-3, and dynorphin in the bovine hypothalamus. PeerJ 2016; 4: e1833. [Medline] [CrossRef]

27. Cardoso RC, Alves BR, Sharpton SM, Williams GL, Amstalden M. Nutritional programming of accelerated puberty in heifers: involvement of pro-opiomelanocortin neurones in the arcuate nucleus. J Neuroendocrinol 2015; 27: 647-657. [Medline] [CrossRef]

28. Alves BR, Cardoso RC, Prezotto LD, Thorson JF, Bedenbaugh M, Sharpton SM, Caraty A, Keisler DH, Tedeschi LO, Williams GL, Amstalden M. Elevated body weight gain during the juvenile period alters neuropeptide Y-gonadotropin-releasing hormone circuitry in prepubertal heifers. Biol Reprod 2015; 92: 46. [Medline] [CrossRef]

29. Smith JT, Clay CM, Caraty A, Clarke IJ. KiSS-1 messenger ribonucleic acid expression in the hypothalamus of the ewe is regulated by sex steroids and season. Endocrinology 2007; 148: 1150-1157. [Medline] [CrossRef]

30. Franceschini I, Lomet D, Cateau M, Delsol G, Tillet Y, Caraty A. Kisspeptin immunoreactive cells of the ovine preoptic area and arcuate nucleus co-express estrogen receptor alpha. Neurosci Lett 2006; 401: 225-230. [Medline] [CrossRef]

31. Matsuda F, Nakatsukasa K, Suetomi Y, Naniwa Y, Ito D, Inoue N, Wakabayashi Y, Okamura H, Maeda KI, Uenoyama Y, Tsukamura H, Ohkura S. The luteinising hormone surge-generating system is functional in male goats as in females: involvement of kisspeptin neurones in the medial preoptic area. J Neuroendocrinol 2015; 27: 57-65. [Medline] [CrossRef]
32. Rometo AM, Krajewski SJ, Voytko ML, Rance NE. Hypertrophy and increased kisspeptin gene expression in the hypothalamic infundibular nucleus of postmenopausal women and ovariectomized monkeys. J Clin Endocrinol Metab 2007; 92: 2744-2750. [Medline] [CrossRef]

33. Watanabe Y, Uenoyama Y, Suzuki J, Takase K, Suetomi Y, Ohkura S, Inoue N, Maeda KI, Tsukamura H. Oestrogen-induced activation of preoptic kisspeptin neurones may be involved in the luteinising hormone surge in male and female Japanese monkeys. J Neuroendocrinol 2014; 26: 909-917. [Medline] [CrossRef]

34. Brailoiu GC, Dun SL, Ohsawa M, Yin D, Yang J, Chang JK, Brailoiu E, Dun NJ. KiSS-1 expression and metastin-like immunoreactivity in the rat brain. J Comp Neurol 2005; 481: 314-329. [Medline] [CrossRef]

35. Smith JT, Cunningham MJ, Rissman EF, Clifton DK, Steiner RA. Regulation of Kiss 1 gene expression in the brain of the female mouse. Endocrinology 2005; 146: 3686-3692. [Medline] [CrossRef]

36. Tomikawa J, Homma T, Tajima S, Shibata T, Inamoto Y, Takase K, Inoue N, Ohkura S, Uenoyama Y, Maeda K, Tsukamura H. Molecular characterization and estrogen regulation of hypothalamic KISS1 gene in the pig. Biol Reprod 2010; 82: 313-319. [Medline] [CrossRef]

37. Adachi S, Yamada S, Takatsu Y, Matsui H, Kinoshita M, Takase K, Sugiura H, Ohtaki T, Matsumoto H, Uenoyama Y, Tsukamura H, Inoue K, Maeda K. Involvement of anteroventral periventricular metastin/kisspeptin neurons in estrogen positive feedback action on luteinizing hormone release in female rats. J Reprod Dev 2007; 53: 367-378. [Medline] [CrossRef]

38. Smith JT, Li Q, Pereira A, Clarke IJ. Kisspeptin neurons in the ovine arcuate nucleus and preoptic area are involved in the preovulatory luteinizing hormone surge. Endocrinology 2009; 150: 5530-5538. [Medline] [CrossRef]

39. Okamura H. Brain atlas of cattle (in Japanese). In: A foundational research for elucidation and estimation of agriculturae, Forestry and Fisheries Research Council. 2002: $41-72$.

40. Jiao Y, Sun Z, Lee T, Fusco FR, Kimble TD, Meade CA, Cuthbertson S, Reiner A. A simple and sensitive antigen retrieval method for free-floating and slide-mounted tissue sections. J Neurosci Methods 1999; 93: 149-162. [Medline] [CrossRef]

41. Ohkura S, Uenoyama Y, Yamada S, Homma T, Takase K, Inoue N, Maeda K, Tsukamura H. Physiological role of metastin/kisspeptin in regulating gonadotropin-releasing hormone (GnRH) secretion in female rats. Peptides 2009; 30: 49-56. [Medline] [CrossRef]

42. Goodman RL, Hileman SM, Nestor CC, Porter KL, Connors JM, Hardy SL, Millar RP, Cernea M, Coolen LM, Lehman MN. Kisspeptin, neurokinin B, and dynorphin act in the arcuate nucleus to control activity of the GnRH pulse generator in ewes. Endocrinology 2013; 154: 4259-4269. [Medline] [CrossRef]

43. Matsuyama S, Ohkura S, Mogi K, Wakabayashi Y, Mori Y, Tsukamura H, Maeda K, Ichikawa M, Okamura H. Morphological evidence for direct interaction between kisspeptin and gonadotropin-releasing hormone neurons at the median eminence of the male goat: an immunoelectron microscopic study. Neuroendocrinology 2011; 94: 323-332. [Medline] [CrossRef]

44. Uenoyama Y, Inoue N, Pheng V, Homma T, Takase K, Yamada S, Ajiki K, Ichikawa M, Okamura H, Maeda KI, Tsukamura H. Ultrastructural evidence of kisspeptingonadotrophin-releasing hormone $(\mathrm{GnRH})$ interaction in the median eminence of female rats: implication of axo-axonal regulation of GnRH release. J Neuroendocrinol 2011; 23: 863-870. [Medline] [CrossRef]

45. Jafarzadeh Shirazi MR, Zamiri MJ, Salehi MS, Moradi S, Tamadon A, Namavar MR, Akhlaghi A, Tsutsui K, Caraty A. Differential expression of RFamide-related peptide, a mammalian gonadotrophin-inhibitory hormone orthologue, and kisspeptin in the hypothalamus of Abadeh ecotype does during breeding and anoestrous seasons. $J$ Neuroendocrinol 2014; 26: 186-194. [Medline] [CrossRef]

46. Gottsch ML, Navarro VM, Zhao Z, Glidewell-Kenney C, Weiss J, Jameson JL, Clifton DK, Levine JE, Steiner RA. Regulation of Kiss1 and dynorphin gene expression in the murine brain by classical and nonclassical estrogen receptor pathways. $J$ Neurosci 2009; 29: 9390-9395. [Medline] [CrossRef]

47. Reames PS, Hatler TB, Hayes SH, Ray DL, Silvia WJ. Differential regulation of estrous behavior and luteinizing hormone secretion by estradiol-17 $\beta$ in ovariectomized dairy cows. Theriogenology 2011; 75: 233-240. [Medline] [CrossRef]

48. Wintermantel TM, Campbell RE, Porteous R, Bock D, Gröne HJ, Todman MG, Korach KS, Greiner E, Pérez CA, Schütz G, Herbison AE. Definition of estrogen receptor pathway critical for estrogen positive feedback to gonadotropin-releasing hormone neurons and fertility. Neuron 2006; 52: 271-280. [Medline] [CrossRef]

49. Zhang C, Tonsfeldt KJ, Qiu J, Bosch MA, Kobayashi K, Steiner RA, Kelly MJ, Rønnekleiv OK. Molecular mechanisms that drive estradiol-dependent burst firing of Kiss neurons in the rostral periventricular preoptic area. Am J Physiol Endocrinol Metab 2013; 305: E1384-E1397. [Medline] [CrossRef]

50. Desroziers E, Mikkelsen J, Simonneaux V, Keller M, Tillet Y, Caraty A, Franceschini I. Mapping of kisspeptin fibres in the brain of the pro-oestrous rat. J Neuroendocrinol 2010; 22: 1101-1112. [Medline] [CrossRef] 